\title{
Galende Díaz, Juan Carlos y Ávila Seoane, Nicolás (2018), El rodado regio hispánico: León y Castilla antes de la unificación (1157-1230), Centro de Estudios Históricos: "Prof. Carlos S. A. Segreti", Instituto de Estudios Históricos UEDD CONICET, Córdoba (Argentina), 835 págs. ISBN: 9789874126047
}

Durante la Edad Media, en las cancillerías de los reyes hispanos, empezó a proliferar en la documentación un signo de validación conocido o llamado indistintamente rota, rueda o signo rodado, cuyo uso daría origen a un tipo documental determinado, el llamado privilegio rodado. Estas rotas, en forma de rueda y más o menos decoradas, serían usadas por autoridades de gran distinción como papas, emperadores, reyes, notarios, entre otros, en determinados privilegios. En la península ibérica, su uso se prolongará a mediados del siglo XII hasta su desaparición a finales del siglo XV, coincidiendo con la aparición del nuevo estado moderno y la nueva forma de organización política y social del reinado de los Reyes Católicos.

El estudio de su uso antes de la unificación de los reinos de León y Castilla cobra especial interés y forma parte de la investigación llevada a cabo por Juan Carlos Galende Díaz y Nicolás Ávila Seoane, ambos profesores del Departamento de Historia y Antropología de América, Ciencias y Técnicas Historiográficas e Historia Medieval de la Universidad Complutense de Madrid (UCM), con una dilatada trayectoria profesional a sus espaldas.

La obra, que ahora nos presentan, El rodado regio hispánico: León y Castilla antes de la unificación (1157-1230), editada por el Centro de Estudios Históricos "Prof. Carlos S. A. Segreti" y financiada con cargo a la Acción Especial AE17/1821505, concedida por el Vicerrectorado de Política Científica, Investigación y Doctorado de la Universidad Complutense de Madrid, muestra un profundo análisis de las fuentes documentales, interiorizando y sacando a la luz el origen, desarrollo y consolidación de este signo de validación, así como pone de relieve de forma sucinta las obras de paleógrafos y diplomatistas de la talla de Riesco Terrero, De Francisco, Ostos Salcedo, Pardo Rodríguez, entre otros, que han trabajado a lo largo de sus carreras investigadoras en las rotas medievales.

Compuesta por doce capítulos, se inicia la obra con una introducción donde se pone de manifiesto la finalidad de este estudio, así como el desarrollo de la investigación realizada por los autores y su posterior organización. El segundo se centra ya en la aparición de la rota y su llegada a la península ibérica, donde se aborda su nacimiento para validar privilegios pontificios solemnes bajo la canci- 
llería de León IX; la consolidación y establecimiento de los textos del campo de Urbano II para finalmente conformar el modelo definitivo bajo la figura de Pascual II. Respetando a este último en los cuarteles de campo y reservando la orla para el lema personal de cada pontífice antecedido de una cruz, da paso a su desarrollo en la Península a partir del año 1157 bajo el mandato de Fernando II de León.

También en este capítulo, en su último epígrafe, los autores se detienen en aquellos raros ejemplos en los que personajes ajenos al episcopado o a la familia real validaran con rueda, como los casos del conde gallego Fernando Pérez de Traba y su nieto el conde Fernando Ponce de Cabrera el Menor, el cual muestra el emblema de su linaje, o el del maestre de Calatrava, Martín Pérez de Siones.

El tercero hace mención a las supuestas rotas antes de 1157, donde la bibliografía más antigua cita ruedas anteriores a dicha fecha que son anacrónicas o falsas, poniendo de manifiesto la documentación generada por los monarcas Ramiro II, Alfonso VII, Fernando [II] de León y Sancho [III] de Castilla.

Siguiendo la filosofía general de la obra, los siguientes capítulos que se presentan (del cuarto al décimo respectivamente) están dedicados a un monarca leonés o castellano, poniéndose de manifiesto el análisis de las ruedas hasta el año 1230 , momento en el que se produce la unificación de ambos reinos por Fernando III. Se corresponderá con los reyes leoneses Fernando II y Alfonso IX y los reyes castellanos Alfonso VIII, Enrique I y Fernando III, este último hasta la muerte de su padre. No podemos tampoco dejar de lado a las reinas: Leonor Plantagenet, cuyo signo será una mano derecha abierta en actitud de bendecir, símbolo de liberalidad; y su hija Berenguela, cuyas dos ruedas, reproducidas en esta obra, tienen la particularidad de ser despachadas una, en su calidad de reina consorte de León, y otra, como reina titular de Castilla, respectivamente.

Cada capítulo abre con una introducción breve de cada rey donde se hace una contextualización del mismo, dando paso al estudio de cada uno de sus modelos, representando sus principales tipos. Por último, se cierra con un catálogo presentado cronológicamente (al final del mes si el diploma no expresa el día, y al término del año si falta el mes), donde cada ficha catalogada recoge una serie de datos sustanciales tales como la signatura, la data completa y el regesto del propio documento, así como si existen o han existido reproducciones del mismo. También se incluyen observaciones sobre la rota: una descripción general, la dimensión de su diámetro exterior, campo y orla, además de la leyenda o la gráfila.

Finaliza la obra con las conclusiones, donde se pone de relieve lo que ha supuesto la culminación de este trabajo y su estudio en la actualidad, así como una extensa bibliografía que nos permite acercarnos a los orígenes de las primeras investigaciones sobre el rodado regio hispánico y su evolución a lo largo de estos años.

Sin duda, queda sobradamente demostrado, que este libro es de suma utilidad para la Diplomática actual, por tratarse de una obra de carácter recopilatorio que aúna en sus páginas el esfuerzo y dedicación de años de estudio sobre el hecho de generar y usar el rodado regio como elemento de validación en un documento 
junto a las rúbricas o sellos de cera o plomo. La gran novedad que presenta es la metodología que emplea y las fuentes de documentación utilizadas, que hacen posible que sea la obra en la cual se ha convertido. Bien es cierto que no es libro que pueda ser leído de una sola vez, todo lo contrario, se trata de una herramienta de imprescindible consulta para todos aquellos especialistas de la materia, así como una interesante y agradable lectura para aquellos que deseen conocer más sobre los elementos de validación en la documentación medieval.

Ana Barrena Gómez Universidad de Málaga 